\title{
Population structure of the Pacific angel shark (Squatina californica) along the northwestern coast of Mexico based on the mitochondrial DNA control region
}

\section{Estructura poblacional del tiburón ángel del Pacífico (Squatina californica) a lo largo de la costa noroccidental de México con base en la regíon control del ADN mitocondrial}

Sergio Ramírez-Amaro ${ }^{1}$, Dení Ramírez-Macías ${ }^{2}$, Ricardo Vázquez-Juárez ${ }^{3 *}$, Sergio Flores-Ramírez ${ }^{4}$, Felipe Galván-Magaña ${ }^{5}$, Jesús N Gutiérrez-Rivera ${ }^{3}$

${ }^{1}$ Universitat de les Illes Balears, Laboratori de Genètica, Carretera de Valldemossa km 7.5, 07122, Palma de Mallorca, Spain.

2 Tiburón Ballena México de ConCIENCIA México, Manatí 4, no. 802, colonia Esperanza III, CP 23090, La Paz, Baja California Sur, México.

${ }^{3}$ Centro de Investigaciones Biológicas del Noroeste, Mar Bermejo 195, colonia Playa Palo de Santa Rita Sur, CP 23096, La Paz, Baja California Sur, México.

${ }^{4}$ Departamento de Biología Marina, Universidad Autónoma de Baja California Sur, Apartado Postal 12-B, CP 23081, La Paz, Baja California Sur, México.

${ }^{5}$ Instituto Politécnico Nacional (IPN), Centro Interdisciplinario de Ciencias Marinas, Av. IPN s/n, colonia Playa Palo de Santa Rita, CP 23096, La Paz, Baja California Sur, México.

* Corresponding author. E-mail: rvazquez04@cibnor.mx

\begin{abstract}
Population structure has direct consequences on species evolution, local adaptation, and the capacity of a metapopulation to adapt to climate change. In this study we assess the genetic structure and demographic history of the Pacific angel shark, Squatina californica, along the northwestern coast of Mexico using the mitochondrial control region. Results showed high levels of genetic diversity and reveal genetic differentiation between the samples from the Pacific coast of the Baja California Peninsula and those from the Gulf of California. These genetic differences are consistent with ontogenetic differences previously reported for $S$. californica off the northwestern coast of Mexico. Our findings can be explained by the low dispersal ability and habitat preference of the angel shark and by the complex geomorphology off the northwestern coast of Mexico. Contrasting historical demographic patterns were observed: population expansion in the gulf and population stability, with a declining trend, in the Pacific; however, more studies are required to corroborate demographic patterns in both populations. Our results point to 2 distinct management units of the Pacific angel shark in the study area, and this may have direct implications for the management and conservation of this species in Mexico.
\end{abstract}

Key words: demersal shark, ecological clusters, genetic differentiation, Gulf of California, Pacific coast.

RESUMEN. La estructura poblacional tiene consecuencias directas sobre la evolución de las especies, la adaptación local y la capacidad de una metapoblación para adaptarse al cambio climático. En el presente estudio, se analizó la estructura genética y la historia demográfica del tiburón ángel del Pacífico, Squatina californica, a lo largo de la costa noroccidental de México con base en la región control del ADN mitocondrial. Los resultados mostraron elevados niveles de diversidad genética y diferenciación genética entre las muestras del Pacífico frente a la península de Baja California y aquellas del golfo de California. Estas diferencias genéticas son consistentes con las diferencias ontogenéticas reportadas previamente para S. californica en la costa noroccidental de México. Los resultados pueden ser explicados por la baja capacidad de dispersión y la preferencia de hábitat de $S$. californica y por la compleja geomorfología frente a la costa noroccidental de México. Además, se observaron diferentes patrones demográficos históricos: la población del golfo exhibió una tendencia a la expansión y la población del Pacífico exhibió estabilidad con tendencia a disminuir; sin embargo, es necesario realizar más estudios para corroborar los patrones demográficos detectados en ambas poblaciones. Los resultados sugieren la presencia de 2 diferentes unidades para la gestión pesquera del tiburón ángel del Pacífico en el área de estudio, lo cual tiene implicaciones directas para la conservación y gestión de esta especie en México.

Palabras clave: tiburón demersal, grupos ecológicos, diferenciación genética, golfo de California, costa del Pacífico. 


\section{INTRODUCTION}

Understanding the spatiotemporal patterns of gene flow among isolated populations has long been a major focus in ecology (Spaet et al. 2015). Sharks are likely to display different patterns of population structure. Low levels of intraspecific genetic differentiation have been detected mainly in highly migrant pelagic species (e.g., Rhincodon typus) across large ocean basins (Vignaud et al. 2014), while high levels of population structure have been detected mainly in demersal species (e.g., Stegostoma fasciatum) on relatively small geographic scales (Dudgeon et al. 2009). Absence of population structure was detected for the deep-water Centroscymnus coelolepis (Veríssimo et al. 2011), whereas almost global panmixia was found for Cetorhinus maximus (Hoelzel et al. 2006). These population patterns are commonly promoted by geographic barriers or dispersal, or can be influenced by environmental gradients throughout continuous areas (Spaet et al. 2015).

Knowing the processes that affect genetic diversity and population structure is crucial for the conservation of exploited species (Arenas et al. 2012). Overfishing can decrease genetic variation through bottlenecks, cause loss of genetically unique stocks, select for early sexual maturation, and ultimately reduce the adaptability of wild populations (Hutchings and Reynolds 2004). Understanding population structure and connectivity of marine resources is an essential prerequisite for devising effective fishery management strategies in at least 2 critical ways: ( $i$ ) the delineation of an appropriate spatial scale for management and (ii) the specification of subareas, nested within broader management units, that must be protected from exploitation (Fogarty and Botsford 2007, Hilário et al. 2015).

The Pacific angel shark, Squatina californica Ayres 1859, is a demersal shark found off the coast of North America, from Alaska to the Gulf of California, where it is associated with soft-bottom habitats (Compagno et al. 2005). It is a lecithotrophic viviparous shark that has low fecundity (10 embryos per year), with gestation lasting 10 months (Compagno et al. 2005, Romero-Caicedo et al. 2016). This species is frequently targeted by the artisanal elasmobranch fishery along the norwestern coast of Mexico (VillavicencioGarayzar 1996, Ramírez-Amaro et al. 2013). The population trend remains unknown, but reported landing data (2003-2015) from Baja California (Mexico) suggest population decline (Ramírez-Amaro et al. 2013). The Pacific angel shark is categorized as Near Threatened in the International Union for Conservation of Nature Red List of Endangered Species, with a suspected population decline approaching $30 \%$ over 3 generations (Cailliet et al. 2016). Currently, no information on stock or structure has been documented for this species.

Assessing the differences in the population structure of a fishery resource is necessary to understand the extent to which populations are genetically isolated from each other

\section{INTRODUCCIÓN}

Entender los patrones espaciales y temporales del flujo génico entre poblaciones aisladas ha sido un objetivo importante de los estudios de ecología (Spaet et al. 2015). Los tiburones muestran diferentes patrones de estructura poblacional. Se han detectado niveles bajos de diferenciación genética intraespecífica principalmente en especies pelágicas altamente migratorias (e.g., Rhincodon typus) en cuencas oceánicas (Vignaud et al. 2014), mientras que se han detectado niveles altos de estructura poblacional principalmente en especies demersales (e.g., Stegostoma fasciatum) a una escala geográfica relativamente pequeña (Dudgeon et al. 2009). Se ha informado de la ausencia de estructura poblacional en el caso del tiburón de aguas profundas Centroscymnus coelolepis (Veríssimo et al. 2011), mientras que Cetorhinus maximus exhibe panmixia a nivel mundial (Hoelzel et al. 2006). Estos patrones poblacionales son comúnmente promovidos por barreras geográficas o dispersión, o pueden ser influenciados por gradientes ambientales en zonas continuas (Spaet et al. 2015).

Para la conservación de especies explotadas es fundamental conocer los procesos que afectan la diversidad genética y la estructura poblacional (Arenas et al. 2012). La sobrepesca puede disminuir la variabilidad genética mediante cuellos de botella, causar la pérdida de poblaciones genéticamente únicas, propiciar a una maduración sexual temprana, y reducir la adaptabilidad de las poblaciones silvestres (Hutchings y Reynolds 2004). Entender la estructura y conectividad poblacional de los recursos marinos es un prerrequisito esencial para desarrollar estrategias para la gestión efectiva de los recursos pesqueros en por lo menos 2 formas críticas: $(i)$ la delineación de una escala espacial apropiada para la gestión y (ii) la especificación de subáreas, dentro de unidades de gestión más amplias, que deben ser protegidas de la explotación (Fogarty y Botsford 2007, Hilário et al. 2015).

El tiburón ángel del Pacífico, Squatina californica Ayres 1859, es una especie demersal que se encuentra a lo largo de la costa occidental de Norteamérica, desde Alaska hasta el golfo de California, donde se asocia con hábitats de fondos blandos (Compagno et al. 2005). Es un tiburón vivíparo lecitotrófico que tiene una baja fecundidad (10 embriones por año) y un periodo de gestación que dura 10 meses (Compagno et al. 2005, Romero-Caicedo et al. 2016). Es una especie objetivo de la pesquería artesanal de elasmobranquios en la costa noroccidental de México (VillavicencioGarayzar 1996, Ramírez-Amaro et al. 2013). Aún se desconoce la tendencia poblacional, pero los datos provenientes de los desembarques (2003-2015) en Baja California (México) sugieren una disminución de la población (Ramírez-Amaro et al. 2013). El tiburón ángel del Pacífico está clasificado como especie Casi Amenazada en la Lista Roja de Especies Amenazadas de la Unión Internacional para la Conservación de la Naturaleza, con una reducción de la población sospechada de casi $30 \%$ en 3 generaciones 
and need different management plans to protect the species (Nielsen and Powers 1995). It is important to select a locus or loci with a relative high mutation rate in order to detect sufficient polymorphism in population-level studies (Heist et al. 1996). The mitochondrial DNA genome includes a small non-coding region known as the mitochondrial control region (mtCR), which serves as the origin of replication for the mitochondrial genome and is usually more variable than other coding genes (Avise 1994). Several shark population studies have used the mtCR to infer processes responsible for observed patterns of spatial genetic differentiation and to identify fishery management and conservation units (see Dudgeon et al. 2012 and references therein). In the present study, we assess the levels of genetic diversity, population structure, and demographic history of the Pacific angel shark along the northwestern coast of Mexico based on mtCR.

\section{MATERIALS AND METHODS}

\section{DNA extraction, amplification, and sequencing}

Sampling was conducted at 2 localities where artisanal fishermen often land elasmobranchs: the port of Ensenada (27 samples) on the western coast of the Baja California Peninsula and El Portugués fishing camp (11 samples) on the eastern coast (Fig. 1). A small piece of muscular tissue was excised from each individual and stored at $4{ }^{\circ} \mathrm{C}$ in absolute ethanol. Genomic DNA was extracted by a standard phenol-chloroform method (Aljanabi and Martinez 1997). The polymerase chain reaction (PCR) was carried out to amplify mtCR using universal primers: cytb-1040 (5'-GGN CAA CCM GTY GAA CAA CC- $\left.3^{\prime}\right)$ and 12 rev 326 (5'-ACT CGT ATA ACG CGG TGG CT-3') (J Sandoval-Castillo pers. comm.). Cycling conditions were as follows: an initial denaturation step at $96^{\circ} \mathrm{C}$ for $5 \mathrm{~min} ; 35$ cycles for $60 \mathrm{~s}$ each at $94{ }^{\circ} \mathrm{C}, 60 \mathrm{~s}$ at $60^{\circ} \mathrm{C}$, and $60 \mathrm{~s}$ at $72^{\circ} \mathrm{C}$; and a final extension step for $10 \mathrm{~min}$ at $72^{\circ} \mathrm{C}$. PCR products were purified using the QIAquick PCR Purification Kit (QIAGEN, Hilden, Germany). Both heavy and light strands were sequenced (Arizona Research Laboratories, Tucson, AZ) using direct sequencing reactions with a 3730XL DNA Analyzer (Applied Biosystems, Carlsbad, CA) and a BigDye Terminator Cycle Sequencing Kit (Applied Biosystems, Foster City, CA). The resulting DNA sequences were imported into ChromasPro v2.0.1 (Technelysium, Brisbane, Australia) and checked for quality and accuracy of nucleotide base assignment, and multiple sequence alignments were obtained using Clustal X implemented in MEGA v3.1 (Kumar et al. 2008).

\section{Analysis of mtCR}

Molecular diversity indices for the mtCR fragment, including the number of polymorphic sites, nucleotide composition, haplotype diversity $(h)$, nucleotide diversity, and nucleotide divergence, were estimated for each sample
(Cailliet et al. 2016). Actualmente no se cuenta con información de la población o estructura para esta especie.

Para entender qué tan genéticamente aisladas están las poblaciones entre sí y los planes de gestión necesarios para proteger las especies es importante evaluar las diferencias en la estructura poblacional de un recurso pesquero (Nielsen y Powers 1995). Es necesario seleccionar un locus o loci con una tasa de mutación relativamente alta para detectar suficiente polimorfismo en los estudios a nivel poblacional (Heist et al. 1996). El ADN mitocondrial o genoma mitocondrial incluye una pequeña región no codificante conocida como la región control del ADN mitocondrial (RCmt), la cual sirve como el origen de replicación para el genoma mitocondrial y usualmente es más variable que otros genes codificantes (Avise 1994). Varios estudios de las poblaciones de tiburones han usado la $\mathrm{RCmt}$ para inferir los procesos responsables de los patrones observados de diferenciación genética espacial e identificar las unidades de gestión y conservación de recursos pesqueros (ver Dudgeon et al. 2012 y las referencias ahí citadas). En el presente estudio se evaluaron los niveles de diversidad genética, la estructural poblacional y la historia demográfica del tiburón ángel del Pacífico en la costa noroccidental de México con base en la RCmt.

\section{MATERIALES Y MÉTODOS}

\section{Extracción, amplificación y secuenciación del ADN}

Se realizaron muestreos en 2 sitios donde pescadores artesanales frecuentemente desembarcan elasmobranquios: el puerto de Ensenada (27 muestras) en la costa occidental de la península de Baja California y el campo pesquero El Portugués (11 muestras) en la costa oriental (Fig. 1). Un pequeño trozo de tejido muscular fue extraído de cada individuo y almacenado a $4{ }^{\circ} \mathrm{C}$ en etanol absoluto. Se extrajo ADN genómico con fenol-cloroformo (Aljanabi y Martinez 1997). La amplificación de la $\mathrm{RCmt}$ se realizó mediante la reacción en cadena de la polimerasa (PCR, por sus siglas en inglés) con cebadores universales: cytb-1040 (5'-GGN CAA CCM GTY GAA CAA CC-3') y 12 rev 326 (5'-ACT CGT ATA ACG CGG TGG CT-3') (J Sandoval-Castillo com. pers.). Las condiciones de amplificación fueron una desnaturalización inicial a $96{ }^{\circ} \mathrm{C}$ durante $5 \mathrm{~min} ; 35$ ciclos de $60 \mathrm{~s}$ a $94^{\circ} \mathrm{C}, 60 \mathrm{~s} \mathrm{a}$ $60{ }^{\circ} \mathrm{C}$ y 60 s a $72{ }^{\circ} \mathrm{C}$; y una extensión final a $72{ }^{\circ} \mathrm{C}$ durante $10 \mathrm{~min}$. Los productos de la PCR fueron purificados con un kit comercial (QIAquick PCR Purification Kit, QIAGEN, Hilden, Alemania). Se secuenciaron las cadenas tanto ligeras como pesadas (Arizona Research Laboratories, Tucson, AZ) mediante reacciones de secuenciación directa con un analizador de ADN 3730XL (Applied Biosystems, Carlsbad, CA) y un kit comercial (BigDye Terminator Cycle Sequencing Kit, Applied Biosystems, Foster City, CA). Las secuencias de ADN obtenidas fueron importadas a ChromasPro v2.0.1 (Technelysium, Brisbane, Australia) y examinadas para calidad y la precisión de la asignación de bases nucleotídicas, 


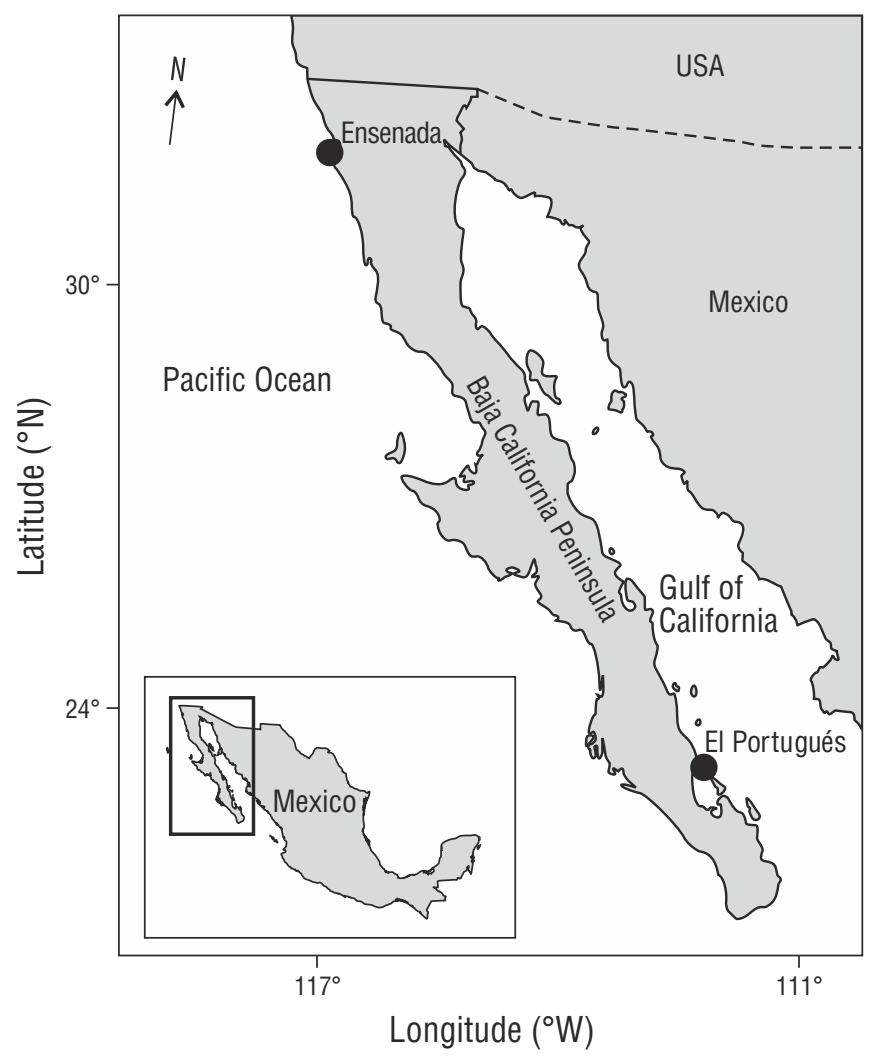

Figure 1. Location of the 2 fishery localities (black circles) on the Baja California Peninsula (Mexico) where samples of Squatina californica were collected: the port of Ensenada and El Portugués fishing camp.

Figura 1. Ubicación de los 2 sitios de desembarque (círculos negros) en la península de Baja California (México) donde se recolectaron muestras de Squatina californica: el puerto de Ensenada y el campo pesquero El Portugués.

using Arlequin v3.1 (Excoffier et al. 2005) and DnaSP v5.0 (Librado and Rozas 2009).

The level of differentiation among populations was assessed by estimating the pairwise $F_{\mathrm{ST}}$ values for $\mathrm{mtCR}$, based on the mean number of pairwise differences among sequences, using Arlequin. The hierarchical genetic structure of populations was assessed for the mtCR by an analysis of molecular variance (AMOVA) implemented in Arlequin. Statistical significance was estimated using 10,000 permutations. The Bayesian phylogeographic and ecological clustering (BPEC) method (Manolopoulou et al. 2011, Manolopoulou and Emerson 2012) was used to detect genetically and geographically distinct population clusters. This test was implemented in R 3.3.1 (R Development Core Team). Different tree and migration event scenarios were explored through the Markov chain Monte Carlo procedure to estimate the geographically clustered structure. Migration events were assumed to occur when a haplotype (with or without a mutation from its parent haplotype) migrated to a obteniéndose alineamientos múltiples de secuencias usando el programa Clustal X implementado en MEGA v3.1 (Kumar et al. 2008).

\section{Análisis de la RCmt}

Se estimaron, usando Arlequin v3.1 (Excoffier et al. 2005) y DnaSP v5.0 (Librado y Rozas 2009), los índices de diversidad molecular para el fragmento de la $\mathrm{RCmt}$ de cada muestra, incluyendo el número de sitios polimórficos, la composición nucleotídica, la diversidad haplotípica $(h)$, la diversidad nucleotídica y la divergencia nucleotídica.

Para evaluar el nivel de diferenciación entre poblaciones se estimaron, con Arlequin, los valores de $F_{\text {ST }}$ por pares para la $\mathrm{RCmt}$, con base en el número promedio de diferencias pareadas entre secuencias. Se evaluó la estructura genética jerárquica de las poblaciones mediante un análisis de varianza molecular implementado en Arlequin. La significancia estadística se estimó con 10,000 permutaciones. Para detectar las aglomeraciones de poblaciones genética y geográficamente distintas se realizó un análisis bayesiano (Manolopoulou et al. 2011, Manolopoulou y Emerson 2012) con el paquete Bayesian Phylogeographic and Ecological Clustering (BPEC) implementado en R 3.3.1 (R Development Core Team). Para estimar la estructura de aglomeración geográfica se examinaron diferentes escenarios de árboles filogenéticos y eventos de migración mediante el método de Montecarlo basado en cadenas de Markov. Se supuso que los eventos de migración suceden cuando un haplotipo (con y sin una mutación de su haplotipo parental) migra a un grupo nuevo. Las entradas para el análisis bayesiano fueron $10^{7}$ iteraciones, 2 dimensiones, 1 parámetro de relajación por parsimonia y un máximo de 3 migraciones.

\section{Análisis de redes y filogenéticos}

Se representaron las relaciones entre los haplotipos de la $\mathrm{RCmt}$ con una red basada en el algoritmo de unión por medianas (median-joining network, Bandelt et al. 1999) que se construyó con los programas DNA Alignment v1.2 y PopART v3.0 (AWC 2007).

Para el análisis filogenético se adoptó un enfoque de inferencia bayesiana (Huelsenbeck y Ronquist 2001, Huelsenbeck et al. 2001). La filogenia bayesiana se estimó usando el modelo GTR $+\mathrm{I}+\mathrm{G}$ como el modelo sustituto seleccionado con el criterio de información bayesiano implementado en MrModeltest v2.3 (Nylander 2004). El análisis de las inferencias bayesianas se realizó en MrBayes v3.1.2 (Ronquist y Huelsenbeck 2003). Se usó el método de Montecarlo con 4 cadenas, las cuales corrieron simultáneamente durante $10^{7}$ iteraciones con muestreo de los árboles cada 10,000 generaciones. Los primeros $25 \%$ de los árboles fueron descartados como burn-in y los restantes fueron usados para construir una filogenia de consenso por la regla de mayoría de $70 \%$. Para la reconstrucción filogenética se usó 
new cluster. The inputs for the BPEC analysis were $10^{7}$ iterations, 2 dimensions, 1 parsimony relaxation parameter, and a maximum of 3 migrations.

\section{Network and phylogenetic analyses}

The relationships among the $\mathrm{mtCR}$ haplotypes were represented with a median-joining network (Bandelt et al. 1999) that was constructed using DNA Alignment v1.2 and PopART v3.0 (AWC 2007).

Phylogenetic analysis was performed by Bayesian inference (Huelsenbeck and Ronquist 2001, Huelsenbeck et al. 2001). The Bayesian phylogeny was estimated using the GTR + I + G model as the substitution model selected with the Bayesian information criterion implemented in MrModeltest v2.3 (Nylander 2004). Bayesian tree inferences were performed using MrBayes v3.1.2 (Ronquist and Huelsenbeck 2003). We used Markov chain Monte Carlo sampling with 4 chains, which ran simultaneously for $10^{7}$ iterations with trees sampled every 10,000 generations. The first $25 \%$ of the trees were discarded as burn-in and the remaining trees were used to construct a $70 \%$ majority-rule concensus phylogeny. For phylogenetic reconstruction Squatina formosa was used as an outgroup (GenBank accession number: KM084865.1).

\section{Demographic history}

Two methods were applied to the mtCR data set to explore the demographic history of the Pacific angel shark samples that showed genetic differentation. First, evidence for population expansion was evaluated with Tajima's $D$ (Tajima 1989) and Fu's $F_{S}$ (Fu 1997) statistics using Arlequin. Second, to further explore the possibility of demographic changes, a mismatch distribution analysis (distribution of pairwise differences) (Rogers and Harpending 1992) was performed for both geographical groups in Arlequin. Mismatch analysis models assume that any population growth or decline will reveal a genetic signature (Rogers and Harpending 1992, Schneider and Excoffier 1999).

\section{RESULTS}

\section{Genetic analysis}

A fragment of $980 \mathrm{bp}$ from the $\mathrm{mtCR}$ was sequenced for all samples (GenBank accession numbers: KP792162to KP792190). The nucleotide composition of this fragment consisted of $21.59 \%$ cytosine, $35.11 \%$ thymine, $29.66 \%$ adenine, and $13.64 \%$ guanine. Altogether, 29 haplotypes were found (Table 1). Overall haplotype and nucleotide sequence diversities were 0.977 and 0.013 , respectively. A total of 19 and 10 haplotypes occurred at the Gulf of California (El Portugués) and Pacific (Ensenada) sites, respectively. The most common haplotypes, GCF5 and GCF7, occurred at the
Squatina formosa como grupo externo (número de acceso en GenBank: KM084865.1).

\section{Historia demográfica}

Se aplicaron 2 métodos al conjunto de datos de la RCmt para examinar la historia demográfica de las muestras del tiburón ángel del Pacífico que mostraron diferenciación genética. Primero, se evaluó la evidencia de una expansión poblacional con los estadísticos D de Tajima (Tajima 1989) y $F_{\mathrm{S}}$ de $\mathrm{Fu}(\mathrm{Fu}$ 1997) en Arlequin. Segundo, para analizar más detenidamente la posibilidad de cambios demográficos, se realizó un análisis de la distribución de diferencias pareadas (mismatch distribution, Rogers y Harpending 1992) en Arlequin para los 2 grupos geográficos. Los modelos suponen que cualquier crecimiento o disminución poblacional mostrará una firma genética (Rogers y Harpending 1992, Schneider y Excoffier 1999).

\section{RESUltados}

\section{Análisis genético}

Se secuenció un fragmento de $980 \mathrm{pb}$ de todas las muestras de la RCmt (números de acceso en GenBank: KP792162 a KP792190). La composición nucleotídica de este fragmento fue de $21.59 \%$ de citosina, $35.11 \%$ de timina, $29.66 \%$ de adenina y $13.64 \%$ de guanina. En total, se encontraron 29 haplotipos (Tabla 1). La diversidad haplotípica total fue de 0.977 y la diversidad nucleotídica total fue de 0.013 . Se identificaron un total de 19 y 10 haplotipos en los sitios del golfo de California (El Portugués) y el Pacífico (Ensenada), respectivamente. Los haplotipos más comunes, GCF5 y GCF7, fueron encontrados en el sitio del golfo. Los 2 sitios de muestreo no compartieron haplotipos.

Los resultados del análisis de varianza molecular y el análisis de pares concordaron. La hipótesis nula de panmixia global en el área de estudio fue rechazada debido a la heterogeneidad genética significativa entre los sitios de muestreo (Tabla 2). El valor de $F_{\mathrm{ST}}$ entre pares fue significativo $\left(F_{\mathrm{ST}}=0.123, P<0.01\right)$ para la comparación entre pares de las muestras del Pacífico y el golfo. Esta diferenciación genética también concuerda con el número de conglomerados identificados en el análisis bayesiano (BPEC). Con base en el conjunto de datos de la $\mathrm{RCmt}$, este análisis mostró mayor probabilidad $(P=0.97)$ en 2 conglomerados, lo que indica que es la mejor estimación del número verdadero de conglomerados genéticos, que claramente corresponden a los sitios del golfo y el Pacífico (Fig. 2).

El árbol filogenético bayesiano para las muestras de S. californica recolectadas en el noroeste de México mostraron 2 conglomerados (Fig. 3): el grupo G que incluye las muestras del golfo y el grupo $\mathrm{P}$ que incluye las muestras del Pacífico. Ambos conglomerados fueron reflejados en la red haplotípica ya que las muestras de los 2 sitios de muestreo no compartieron haplotipos (Fig. 4). 
Table 1. Genetic diversity indices based on the mitochondrial control region sequences of Squatina californica from the Gulf of California and the Pacific coast of the Baja California Peninsula: $n$, number of samples; PS, number of polymorphic sites; SN, number of substitutions; $\mathrm{Tr}$, number of transitions; Tv, number of transversions; $\mathrm{NH}$, number of haplotypes found; $h$, haplotype diversity; $\pi$, nucleotide diversity. The asterisk indicates statistical significance at $P<0.05$.

Tabla 1. Índices de diversidad genética con base en las secuencias de la región control mitocondrial de Squatina californica del golfo de California y el océano Pacífico frente a la península de Baja California: $n$, número de muestras; PS, número de sitios polimórficos; SN, número de sustituciones; Tr, número de transiciones; Tv, número de transversiones; NH, número de haplotipos encontrados; $h$, diversidad haplotípica; $\pi$, diversidad nucleotídica. El asterisco indica significación estadística a $P<0.05$.

\begin{tabular}{lccccccccccc}
\hline Sampling area & $n$ & PS & SN & Tr & Tv & NH & $h$ & $\pi$ & $D^{1}$ & $F_{\mathrm{S}}^{2}$ \\
\hline Gulf of California & 27 & 52 & 54 & 18 & 36 & 19 & 0.982 & 0.008 & $-1.978^{*}$ & $-2.985^{*}$ \\
Pacific Ocean & 11 & 90 & 90 & 17 & 73 & 10 & 0.957 & 0.055 & $-1.875^{*}$ & $-2.377^{*}$ \\
\hline Total & 38 & 127 & 134 & 33 & 101 & 29 & 0.977 & 0.013 & \\
\hline
\end{tabular}

${ }^{1}$ Tajima (1989); ${ }^{2} \mathrm{Fu}(1997)$

gulf site. There were no shared haplotypes between sampling areas.

The results of the molecular variance and pairwise analyses were concordant. The null hypothesis of global panmixia across the study area was rejected because there was significant genetic heterogeneity between sampling areas (Table 2). The pairwise $F_{\mathrm{ST}}$ value was significant $\left(F_{\mathrm{ST}}=0.123, P<0.01\right)$ for the pairwise comparison between the Pacific and Gulf of California samples. This genetic differentiation is also consistent with the number of clusters identified by BPEC. Based on the mtCR data set, BPEC revealed the highest probability $(P=0.97)$ at 2 clusters, indicating this as the best estimate of the true number of genetic clusters, which clearly correspond to the gulf and Pacific areas (Fig. 2).

The Bayesian phylogenetic tree for the $S$. californica samples collected off northwestern Mexico showed 2 clusters (Fig. 3), the G cluster comprising the gulf samples and the $P$ cluster comprising the Pacific samples. Both clusters were reflected in the haplotype network because no haplotypes were shared between the Pacific and the gulf samples (Fig. 4).

\section{Demographic history}

The unimodal mismatch distribution analysis (Fig. 5a), together with the negative values of Tajima's $D$ and Fu's $F_{\mathrm{S}}$ statistics (Table 1), indicated a recent population expansion scenario for the gulf population. In contrast, the mismatch distribution analysis showed a multimodal distribution for the Pacific population, suggesting demographic stability (Fig. 5b).

\section{Discussion}

The present study provides a first approach to learning the genetic diversity, population structure, and demographic history of $S$. californica off northwestern Mexico using mtCR.

\section{Historia demográfica}

El análisis de la distribución de diferencias pareadas muestra una distribución unimodal para la población del golfo (Fig. 5a); esto, junto con los valores negativos de los estadísticos de Tajima $(D)$ y Fu $\left(F_{\mathrm{S}}\right)$ (Tabla 1$)$, indica un escenario de expansión poblacional reciente para esta población. En contraste, el análisis muestra una distribución multimodal para la población del Pacífico, lo que sugiere estabilidad demográfica (Fig. 5b).

\section{DISCUSIÓN}

Este trabajo constituye un primer intento para conocer la diversidad genética, la estructura poblacional y la historia demográfica de $S$. californica en el noroeste de México usando la RCmt. La secuencia de la RCmt de esta especie de tiburón es más corta que la de la mayoría de peces cartilaginosos ( 1,200 pb, Stoner et al. 2003). La diversidad haplotípica total fue alta, principalmente debido a la presencia de varios haplotipos únicos. Estos valores altos de diversidad son similares a otros valores obtenidos para $S$. californica en el golfo de California ( $h=0.97$; Grijalva-Chon et al. 2002). Se podría atribuir esta alta diversidad haplotípica y nucleotídica a las altas tasas de mutación que comúnmente se registran en la RCmt (Randi 2000).

Dados los niveles significativos de heterogeneidad y diferenciación genética y la falta de haplotipos compartidos entre las muestras del Pacífico y el golfo, se sugiere que no ha habido suficiente flujo génico entre ambos sitios. De hecho, esta división de población se observó en un análisis filogenético de tiburones ángel (género Squatina) realizado por Stelbrink et al. (2009). La variación genética regional observada en nuestro estudio podría estar vinculada a las diferencias ontogenéticas de $S$. californica entre los sitios de muestreo. La longitud a la madurez sexual (LMS) y la longitud total máxima (LTM) de los individuos del golfo son menores $(\mathrm{LMS}=70.0-77.7 \mathrm{~cm}$; LTM $=88-99 \mathrm{~cm})$ que las de los individuos del Pacífico $(\mathrm{LMS}=99 \mathrm{~cm} ; \mathrm{LTM}=117 \mathrm{~cm}$ ) 
Table 2. Variance of pairwise genetic distances and estimated nucleotide divergence $(K)$ based on the mitochondrial control region sequences of Squatina californica from waters off northwestern Mexico.

Tabla 2. Variabilidad de las distancias genéticas pareadas y la divergencia nucleotídica estimada $(K)$ con base en las secuencias de la región control del ADN mitocondrial de Squatina californica del noroeste de México.

\begin{tabular}{lccccc}
\hline Source of variation & Variance & $\%$ total & $P$ & $F_{\mathrm{ST}}$ & $K(\%)$ \\
\hline Among populations & 3.77 & 44.51 & 0.00 & 0.4451 & 2.13 \\
Within populations & 4.70 & 55.49 & & & \\
\hline
\end{tabular}

The mtCR sequence of this shark species is shorter than that observed in most cartilaginous fishes $(\sim 1,200 \mathrm{bp}$, Stoner et al. 2003). Overall haplotypic diversity was high, mainly due to the presence of many unique haplotypes. These high diversity values are similar to those reported for Pacific angel sharks in the Gulf of California ( $h=0.97$; Grijalva-Chon et al. 2002). High haplotype and nucleotide diversity could likely be due to high mutation rates commonly recorded in the mtCR (Randi 2000).

Given the significant levels of genetic heterogeneity and differentiation and the lack of shared haplotypes between the Pacific and gulf samples, we suggest that there has not been sufficient gene flow between both areas. In fact, this population division was observed in the global phylogenetic analysis of angel shark (genus Squatina) samples performed by Stelbrink et al. (2009). The regional genetic variation observed in our study could be linked to ontogenetic differences in S. californica between study areas. Length at sexual maturity (LSM) and maximum total length (MTL) are lower in individuals from the gulf area $(\mathrm{LSM}=70.0-77.7 \mathrm{~cm}$; $\mathrm{MTL}=88-99 \mathrm{~cm})$ than in individuals from the Pacific area $(\mathrm{LSM}=99 \mathrm{~cm} ;$ MTL $=117 \mathrm{~cm})$ (Villavicencio-Garayzar 1996, Romero-Caicedo et al. 2016). Morphological differences and genetic differentiation are both in agreement with the population structure of this species in the study area.

The genetic differentiation observed in the Pacific angel shark can be attributed to the low dispersal ability of this species because of its life history traits, particularly its preference for coastal and benthic habitats and the lack of pelagic development stages such as the larval stage (Compagno 2005). In general, angel shark species have limited ability for sustained swimming due to their morphological and anatomical features, which limit swim power and suggest low dispersal potential and short migration events (Pittenger 1984). Taking into account the characteristics of S. californica, we consider that the submarine canyons constitute a natural barrier for its dispersal. Geomorphology off northwestern Mexico is complex, and there are numerous submarine canyons and great depths (at the mouth of the Gulf of California, the ocean basin drops to over $3,000 \mathrm{~m}$ ) (Gutiérrez et al.

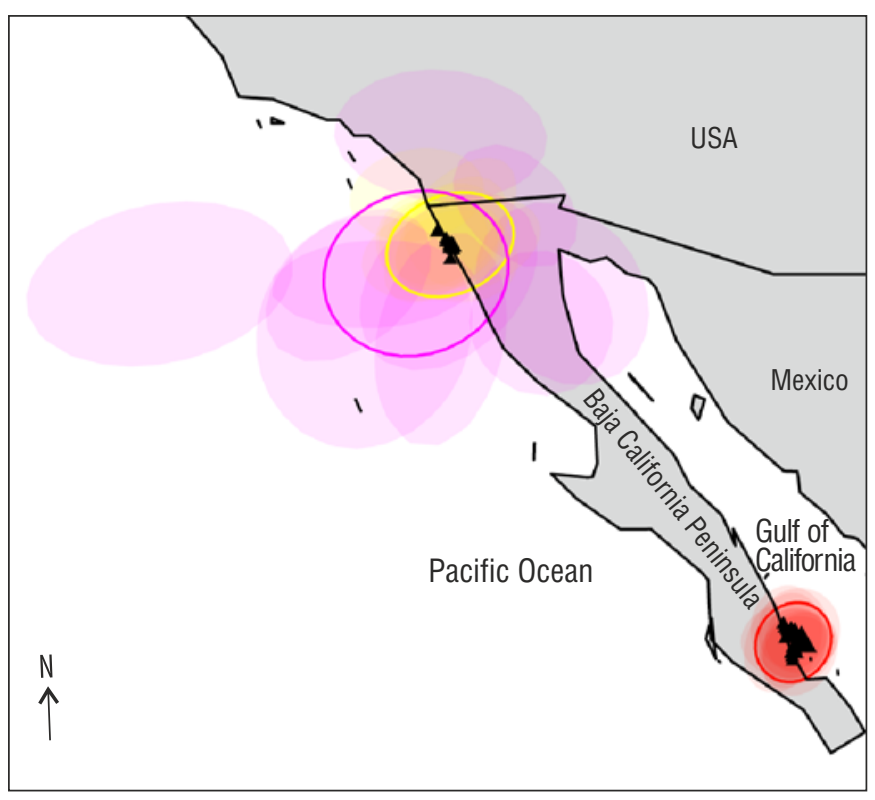

Figure 2. Results from Bayesian phylogeographic and ecological clustering analysis based on the mitochondrial control region sequences of Squatina californica from the Pacific coast of the Baja California Peninsula and the Gulf of California. The simulated contour areas are centered for each population cluster, and the shaded areas show the radius of $50 \%$ concentration contours around it.

Figura 2. Resultados del análisis bayesiano de grupos filogeográficos y ecológicos con base en las secuencias de la región control mitocondrial de Squatina californica de la costa occidental (océano Pacífico) y la costa oriental (golfo de California) de la península de Baja California. Las áreas de contorno simuladas están centradas en cada grupo poblacional y las áreas sombreadas muestran el radio de contornos de concentración de $50 \%$ alrededor del grupo.

(Villavicencio-Garayzar 1996, Romero-Caicedo et al. 2016). Las diferencias tanto morfológicas como genéticas concuerdan con la estructura poblacional de esta especie en el área de estudio.

La diferenciación genética observada en $S$. californica puede atribuirse a la baja capacidad de dispersión de esta especie debido a sus rasgos de historia de la vida, particularmente su preferencia por hábitats costeros y bentónicos y la falta de etapas de desarrollo pelágico como el estadio larval (Compagno 2005). En general, las especies de tiburones ángel tienen una capacidad limitada para la natación sostenida debido a sus características morfológicas y anatómicas, que limitan la potencia de nado y sugieren un bajo potencial de dispersión y migraciones de corta duración (Pittenger 1984). Tomando en cuenta las características de $S$. californica, consideramos que los cañones submarinos constituyen una barrera natural para su dispersión. La morfología del fondo marino en el noroeste de México es compleja. Hay numerosos cañones submarinos y las profundidades son grandes (en la boca del golfo de California la cuenca 


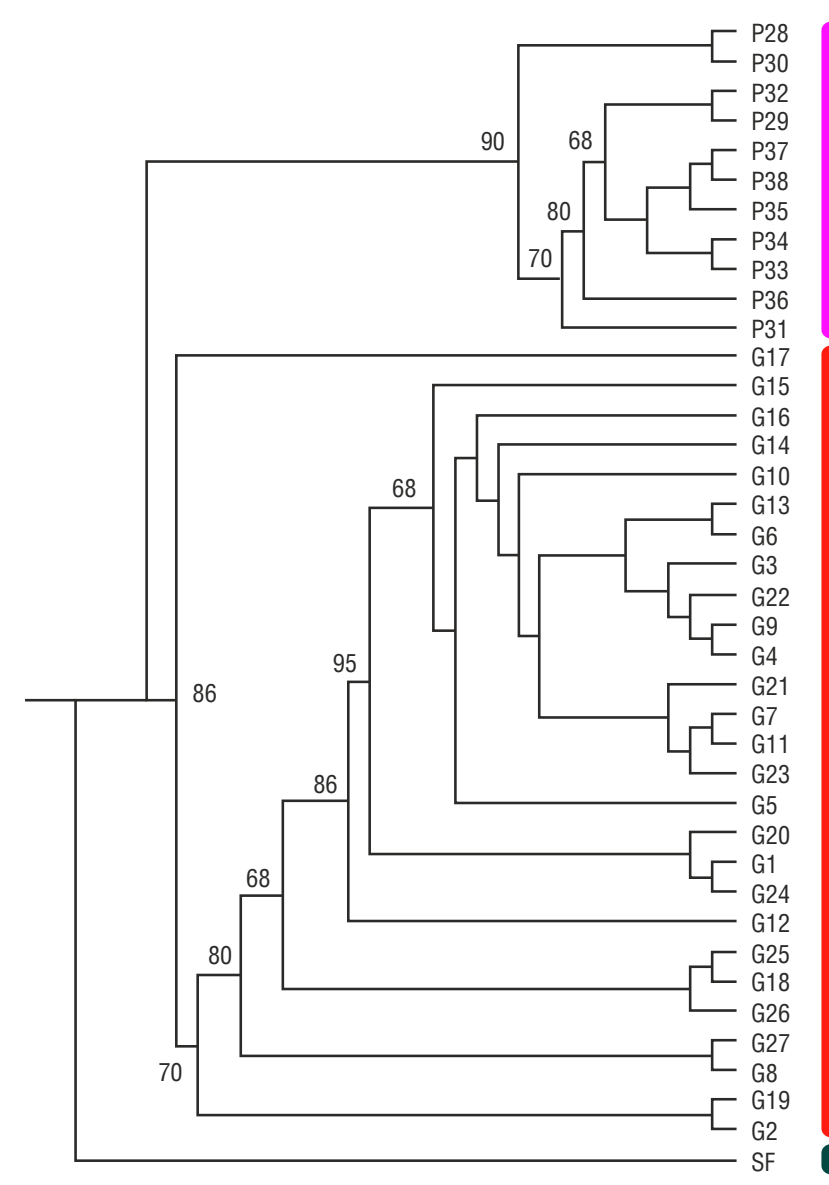

Figure 3. Bayesian phylogenetic reconstruction based on the mitochondrial control region sequences of Squatina californica. Posteriori probabilities are indicated in the nodes. Squatina formosa (SF) was used as the outgroup. P, sample from the Pacific coast of the Baja California Peninsula; G, sample from the Gulf of California. Colors show the clusters according to the Bayesian phylogeographic and ecological clustering results.

Figura 3. Reconstrucción filogenética bayesiana con base en las secuencias de la región control mitocondrial de Squatina californica. Se indican las probabilidades a posteriori en los nodos. Se usó Squatina formosa (SF) como grupo externo. P, muestra del océano Pacífico frente a la península de Baja California; G, muestra del golfo de California. Los colores muestran las agrupaciones según los resultados del análisis bayesiano de grupos filogeográficos y ecológicos.

2004). Furthermore, the continental shelf along the Pacific coast of Baja California is typically narrow (usually $<20 \mathrm{~km}$ ), with great depths close to it (Allen and Horn 2006). The effect of deep marine basins as barriers to dispersal has also been suggested for the Pacific angel shark in waters between the northern and southern Channel Islands (California) (Gaida 1997) and even for other demersal elasmobranchs such as the thornback ray (Raja clavata, Chevolot et al. 2006) and the nurse shark (Ginglymostoma cirratum, Karl et al. 2012).

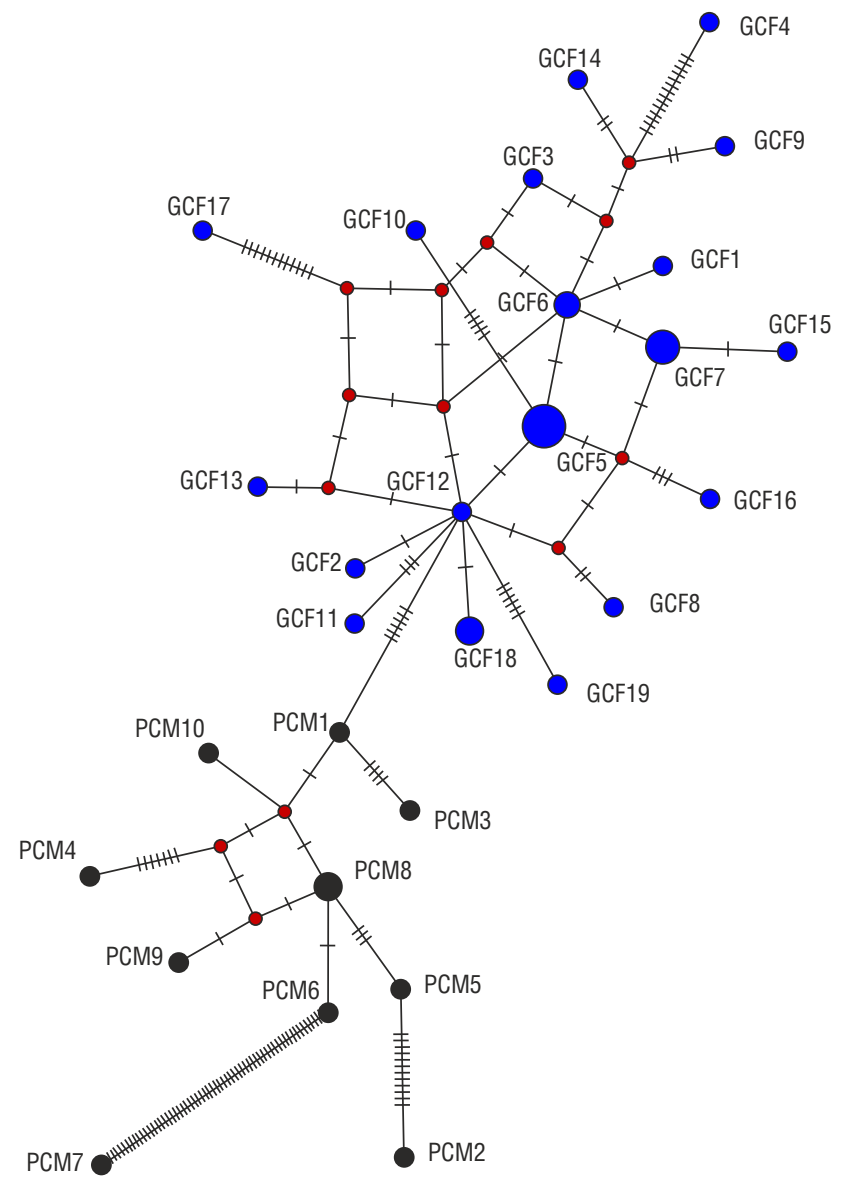

Figure 4. Haplotype network based on the mitochondrial control region sequences of Squatina californica. Black circles indicate haplotypes from the Pacific coast of the Baja California Peninsula (PCM) and blue circles indicate haplotypes from the Gulf of California (GCF). Relative area of circles reflects sample size and the red nodes represent possible haplotype ancestors. Concerning bars represent mutation steps.

Figura 4. Red haplotípica con base en las secuencias de la región control del ADN mitocondrial de Squatina californica. Los círculos negros indican los haplotipos del océano Pacífico frente a la península de Baja California (PCM) y los círculos azules indican los haplotipos del golfo de California (GCF). El área relativa de los círculos refleja el tamaño de la muestra y los nodos rojos representan posibles haplotipos ancestrales. Las barras representan los pasos de mutación.

oceánica alcanza una profundidad de más de 3,000 m) (Gutiérrez et al. 2004). En la costa del Pacífico de Baja California, la plataforma continental tiende a ser angosta $(<20 \mathrm{~km})$ y profunda (Allen y Horn 2006). Ya se había sugerido que las cuencas marinas profundas actúan como barreras para la dispersión del tiburón ángel del Pacífico entre las islas del Canal de California (Gaida 1997), así como de otros elmasmonbranquios como la raya Raja clavata (Chevolot et al. 2006) y el tiburón Ginglymostoma cirratum (Karl et al. 2012). 


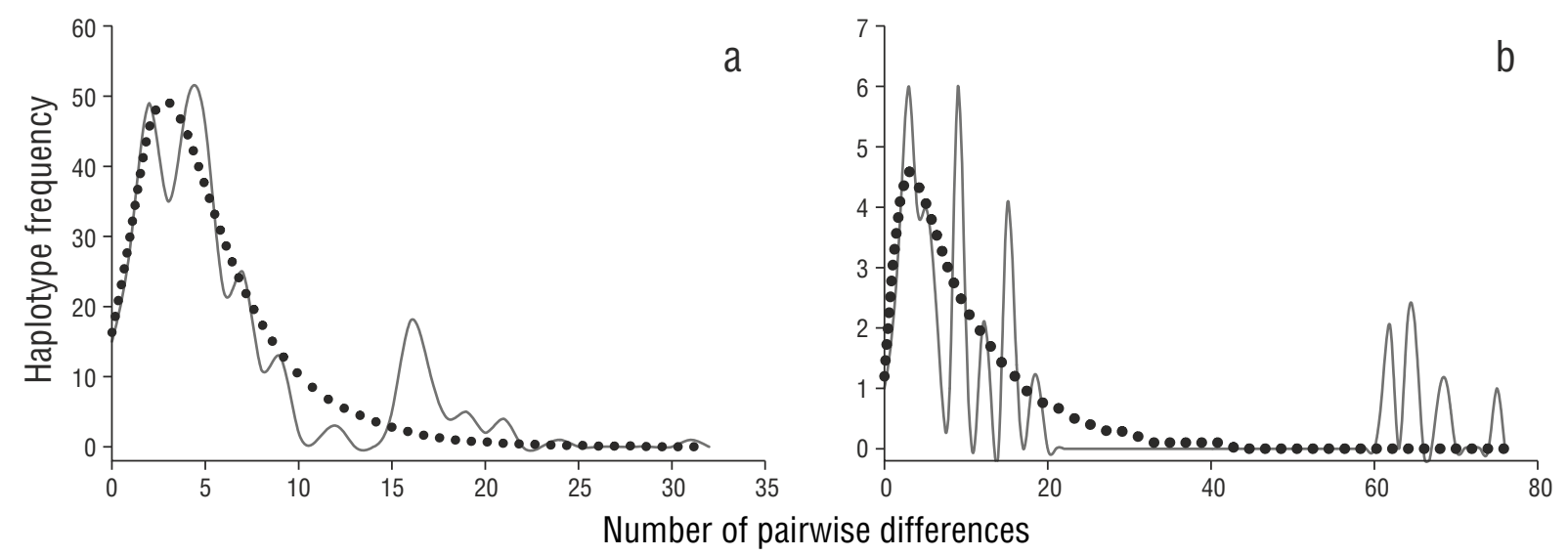

Figure 5. Pairwise mismatch distribution of relative effective population size of Squatina californica based on the mitochondrial control region sequences of samples from the (a) Gulf of California and (b) Pacific coast of the Baja California Peninsula. The solid line represents expected frequency and the dotted line represents observed frequency.

Figura 5. Distribución de diferencias pareadas del tamaño efectivo de la población de Squatina californica con base en las secuencias de la región control del ADN mitocondrial de las muestras del (a) golfo de California y (b) océano Pacífico frente a la península de Baja California. La línea continua representa la frecuencia esperada y la línea punteada representa la frecuencia observada.

The Baja California Peninsula has been reported as an important biogeographic barrier for several species of elasmobranchs such as the shovelnose guitarfish (Rhinobatos productus, Sandoval-Castillo et al. 2004), California butterfly ray (Gymnura marmorata, Smith et al. 2009), golden cownose ray (Rhinoptera steindachneri, Sandoval-Castillo and Rocha-Olivares 2011), and banded guitarfish (Zapteryx exasperata, Castillo-Páez et al. 2014). The dynamic history of the area as a transition zone (Álvarez-Borrego 1983) could have produced multiple events of population fragmentation, likely influencing the genetic differentiation in elasmobranch populations (Sandoval-Castillo and Beheregaray 2015).

Reproductive behavior may also promote the observed genetic differentiation of Pacific angel shark populations. Philopatric behavior reduces the possibility of gene flow among breeding areas (Dudgeon et al. 2012). Female reproductive philopatry to nursery areas has been recorded for several elasmobranchs, such as the zebra shark (Stegostoma fasciatum, Dudgeon et al. 2009), thornback ray (R. clavata, Chevolot et al. 2006), and small-spotted catshark (Scyliorhinus canicula, Kousteni et al. 2015), and it even has been associated with the genetic variation in the banded guitarfish ( $Z$. exasperata, Castillo-Páez et al. 2014) between the Pacific and gulf areas. However, no tagging or biological marker studies are available to determine whether S. californica returns to the same breeding areas every reproductive season. In this sense, tagging studies are required to assess reproductive philopatry.

In the present study, we found private or unique haplotypes for both sampling areas probably due to the small sample size (Kalinowski 2004). An adequate sampling scheme is needed to properly analyze biological questions regarding geographic genetic structure (Mona et al. 2014). Small sample sizes can overestimate population division and
Se ha documentado que la península de Baja California es una barrera biogeográfica para varias especies de elasmobranquios, como los peces guitarra Rhinobatos productus (Sandoval-Castillo et al. 2004) y Zapteryx exasperata (Castillo-Páez et al. 2014), la raya mariposa californiana Gymnura marmorata (Smith et al. 2009) y la raya nariz de vaca Rhinoptera steindachneri (Sandoval-Castillo y RochaOlivares 2011). La historia de la dinámica del área como una zona de transición (Álvarez-Borrego 1983) podría haber causado múltiples eventos de fragmentación poblacional que probablemente influenciaron la diferenciación genética en las poblaciones de elasmobranquios (Sandoval-Castillo y Beheregaray 2015).

El comportamiento reproductivo también puede promover la diferenciación genética entre las poblaciones de tiburón ángel del Pacífico. Un comportamiento filopátrico reduce la posibilidad de flujo génico entre las zonas de reproducción (Dudgeon et al. 2012). La filopatría de las hembras a las zonas de reproducción y crianza ha sido documentado para varios elasmobranquios, incluyendo el tiburón cebra Stegostoma fasciatum (Dudgeon et al. 2009), la raya R. clavata (Chevolot et al. 2006) y la pintarroja Scyliorhinus canicula (Kousteni et al. 2015), e incluso se ha asociado con la variabilidad genética del pez guitarra $Z$. exasperata (Castillo-Páez et al. 2014) entre el Pacífico y el golfo. Sin embargo, no se dispone de estudios de marcado o de marcadores biológicos para determinar si S. californica regresa a las mismas zonas de reproducción cada temporada reproductiva. Por lo tanto, se requieren de estudios de marcado para evaluar la filopatría reproductiva.

En el presente estudio encontramos haplotipos privados o únicos para ambos sitios de muestreo probablemente debido al pequeño tamaño de la muestra (Kalinowski 2004). Se requiere de un plan de muestreo adecuado para analizar 
fail to yield statistical significance in the pairwise AMOVA (Sinclair and Hobbs 2008). Because of this and given the genetic variation, we consider that fine-scale sampling and larger sample sizes are required to detect intermediate populations.

The demographic analyses suggest a sudden growth for the gulf population, which could be associated with the formation of the Gulf of California. The formation of the Gulf of California (Pleistocene, Jacobs et al. 2004) provided new habitat and propitious conditions. The Pacific population showed patterns of population stability, but the mismatch distribution showed a ragged distribution (Fig. 5a), indicating a population in disequilibrium that is less likely to expand. A similar distribution has been documented for the Guadalupe fur seal (Arctocephalus townsendi, Weber et al. 2004), suggesting a substantial loss of genetic variability associated with a recent population bottleneck. Divergence time studies using more molecular markers are nevertheless required to adequately assess the demographic history of both Pacific angel shark populations.

Our results have implications for the design of management and conservation policies because they suggest 2 populations or stocks for the Pacific angel shark off northwestern Mexico. The adoption of genetic and evolutionary criteria in the management of natural resources has led to the recognition of management units, which represent functionally independent populations, or groups of populations, characterized by low levels of gene flow (Moritz 1994). In this sense, we suggest that both populations should be considered as separate management units. Future stock assessment should be done separately for each population. In Mexico, however, tools for legislation (e.g., NOM-029-PESC) do not account for population or stock structure or population dynamics of shark resources. An inadequate management strategy can cause a stock to collapse or lead to local extirpation with ecological and economic consequences (Dulvy and Forrest 2010).

In particular, demographic analyses for the Pacific population of $S$. californica suggests population stability but with tendency to decline, likely due to the effect of fisheries. Reported landing data (2003-2015) from Baja California suggest that Pacific angel shark landings declined by $>99 \%$ (Cailliet et al. 2016). This shark species has been heavily exploited off the western coast of the Baja California Peninsula (e.g., San Ignacio Lagoon and Magdalena Bay) over the past 3 decades (mainly in the 1980s and 1990s; Villavicencio-Garayzar and Abitia-Cardenas 1994, Leet et al. 2001). A recent study of elasmobranch fisheries along the western coast of the Baja California Peninsula (RamírezAmaro et al. 2013) found that Pacific angel sharks were not reported in previously known landing areas. It is therefore necessary to pay attention to the current and future effects of fishing on the population of $S$. californica off the western coast of the Baja California Peninsula. correctamente las cuestiones biológicas sobre la estructura genética espacial (Mona et al. 2014). Los tamaños de muestra pequeños pueden sobreestimar la división de población y pueden no producir la significación estadística en el análisis de varianza molecular (Sinclair y Hobbs 2008). Por esta razón y dada la variación genética, consideramos que se requieren tamaños de muestra más grandes y muestreos a una escala más fina para detectar poblaciones intermedias.

La historia demográfica sugiere un crecimiento repentino de la población del golfo, que podría estar asociado con la formación del golfo de California. La formación del golfo de California (Pleistoceno, Jacobs et al. 2004) proporcionó un hábitat nuevo y condiciones propicias. La población del Pacífico mostró un patrón de establidad; sin embargo, el análisis de la distribución de diferencias pareadas mostró una distribución desigual (Fig. 5a), lo cual indica una población en desequilibrio con menor posibilidad de expansión. Se ha documentado una distribución similar para el lobo fino de Guadalupe Arctocephalus townsendi (Weber et al. 2004), lo que sugiere una pérdida sustancial de la variabilidad genética asociada a un cuello de botella poblacional reciente. Se requieren estudios del tiempo de divergencia usando más marcadores moleculares para evaluar adecuadamente la demografía de ambas poblaciones de S. californica.

Nuestros resultados tienen implicaciones para el diseño de políticas de gestión y conservación ya que sugieren 2 poblaciones de $S$. californica en aguas del noroeste de México. La adopción de criterios genéticos y evolutivos en el manejo de recursos naturales ha llevado al reconocimiento de unidades de gestión, que representan poblaciones funcionalmente independientes, o grupos de poblaciones, caracterizados por niveles bajos de flujo génico (Moritz 1994). Nosotros sugerimos que ambas poblaciones deberían ser consideradas como unidades de gestión separadas. Futuras evaluaciones deberían hacerse por separado para cada población. En México, sin embargo, las herramientas legislativas (e.g., NOM-029-PESC) no toman en cuenta la estructura o dinámica poblacional de los recursos de tiburones. Una estrategia de gestión inadecuada puede provocar el colapso de una población o la extirpación local con consecuencias ecológicas y económicas (Dulvy y Forrest 2010).

En particular, la historia demográfica de la población de $S$. californica del Pacífico sugiere estabilidad poblacional pero con una tendencia a disminuir, probablemente debido a los efectos de las pesquerías. Los datos provenientes de los desembarques (2003-2015) en Baja California sugieren que las capturas de $S$. californica disminuyeron en $>99 \%$ (Cailliet et al. 2016). Esta especie ha sido fuertemente explotada en la costa occidental de la península de Baja California (e.g., bahía Magdalena y laguna de San Ignacio) durante las pasadas 3 décadas (especialmente en los años ochenta y noventa; Villavicencio-Garayzar y Abitia-Cardenas 1994, Leet et al. 2001). Un estudio reciente de las pesquerías de elasmobranquios en la costa occidental de la península (Ramírez-Amaro et al. 2013) documentó la ausencia de S. californica en sitios 


\section{ACKNOWLEDGMENTS}

The authors acknowledge funding support from the National Council for Science and Technology (CONACYT, Mexico). FGM thanks IPN for the granted fellowships (COFFA, EDI). We thank Leonardo Castillo Géniz (INAPESCA), Daniel Cartamil (Scripps Institution of Oceanography), IEMANYA OCEANICA A.C., and the CICIMAR elasmobranch team for collecting the samples. Hever Latisnére provided assistance with laboratory analyses. Adrián Munguía helped with sequencing procedures. Gerardo González Barba provided helpful comments. Two anonymous reviewers and the editor are also greatly acknowledged for their constructive comments that improved the quality of the manuscript.

\section{REFERENCES}

Aljanabi SM, Martinez I. 1997. Universal and rapid salt-extraction of high quality genomic DNA for PCR-based techniques. Nucleic Acids Res. 25(22): 4692-4693.

Allen LG, Horn MH. 2006. The Ecology of Marine Fishes. University of California Press, Berkeley, CA, 670 pp.

Álvarez-Borrego J. 1983. Gulf of California. In: Ketchum BH (ed.), Estuaries and Enclosed Seas. Ecosystems of the World. Elsevier Publishing, Oxford, pp. 427-449.

Arenas M, Ray N, Currat M, Excoffier L. 2012. Consequences of range contractions and range shifts on molecular diversity. Mol. Biol. Evol. 29: 207-218.

Avise JC. 1994. Molecular Markers, Natural History and Evolution. Chapman and Hall, Springer, New York, 511 pp.

[AWC] Allan Wilson Centre. 2007. PopART (Population Analysis with Reticulate Trees). Free Software Foundation, Inc. [Accessed 21 February 2016] http://popart.otago.ac.nz/ index.shtml

Bandelt HJ, Forster P, Rol A. 1999. Median-Joining networks for inferring intraespecific phylogenies. Mol. Biol. Evol. 16: 37-48.

Cailliet GM, Chabot CL, Nehmens MC, Carlisle AB. 2016. Squatina californica. The IUCN Red List of Threatened Species 2016: e.T39328A80671059. [Accessed 24 July 2016] http:// dx.doi.org/10.2305/IUCN.UK.2016-2.RLTS.T39328A80671059.en

Castillo-Páez A, Sosa-Nishizaki O, Sandoval-Castillo J, GalvánMagaña F, Rocha-Olivares A. 2014. Strong population structure and shallow mitochondrial phylogeny in the banded guitarfish, Zapteryx exasperata (Jordan and Gilbert 1880), from the northern Mexican Pacific. J. Hered. 105(1): 91-100. http://dx.doi.org/10.1093/jhered/est067

Chevolot M, Hoarau G, Rijnsdorp AD, Stam WT, Olsen JL. 2006. Phylogeography and population structure of thornback rays (Raja clavata L. Rajidae). Mol. Ecol. 15: 3693-3705.

Compagno L, Dando M, Fowler S. 2005. Sharks of the World. Princeton University Press, 496 pp.

Dudgeon CL, Blower DC, Broderick D, Giles JL, Holmes BJ, Kashiwagi T, Krück NC, Morgan JAT, Tillett BJ, Ovenden JR. 2012. A review of the application of molecular genetics for fisheries management and conservation of sharks and rays. J. Fish Biol. 80(5): 1789-843. http://dx.doi.org/10.1111/j.1095-8649.2012.03265.x

Dudgeon CL, Broderick D, Ovenden JR. 2009. IUCN classification zones concord with, but underestimate, the population genetic structure of the zebra shark Stegostoma fasciatum in the IndoWest Pacific. Mol. Ecol. 18(2): 248-261.

http://dx.doi.org/10.1111/j.1365-294X.2008.04025.x de desembarque conocidos. Por lo tanto, es necesario prestar atención a los efectos actuales y futuros de la pesca sobre la población de $S$. californica en el Pacífico frente a la costa de la península de Baja California.

\section{AgRAdecimientos}

Este trabajo recibió apoyo financiero del Consejo Nacional de Ciencia y Tecnología (CONACYT, México). FGM agradece el apoyo económico proporcionado por el Instituto Politécnico Nacional a través de los programas COFFA y EDI. Agradecemos a Leonardo Castillo Géniz (INAPESCA), Daniel Cartamil (Scripps Institution of Oceanography), IEMANYA OCEANICA A.C. y el equipo de elasmobranquios del CICIMAR la recolección de las muestras. Hever Latisnére participó en los análisis de laboratorio, Adrián Munguía ayudó con los precidimientos de secuenciación y Gerardo González Barba proporcionó comentarios valiosos. Los comentarios constructivos de 2 revisores anónimos y el editor ayudaron a mejorar la calidad del trabajo.

Traducido al español por Christine Harris.

Dulvy NK, Forrest RE. 2010. Life histories, population dynamics, and extinction risks in Chondrichthyans. In: Carrier JC, Musick JA, Heithaus MR (eds.), Sharks and their Relatives II: Biodiversity, Adaptive Physiology, and Conservation. CRC Press, Boca Raton, FL, pp. 639-679.

Excoffier L, Laval G, Schneider S. 2005. ARLEQUIN v. 3.1: An integrated software package for population genetics data analysis. Evol. Bioinform. Online 1: 47-50.

$\mathrm{Fu}$ YX. 1997. Statistical tests of neutrality of mutations against population growth, hitchhiking and background selection. Genetics 147(2): 915-925.

Gaida IH. 1997. Population structure of the Pacific angel shark, Squatina californica (Squatiniformes: Squatinidae), around the California Channel Islands. Copeia 4: 738-744.

Grijalva-Chon JM, Kaichi A, Numachi K. 2002. Homogeneidad genética en tiburón angelito (Squatina californica) del Golfo de California, evidencia por análisis PCR-RFLP de la región control del ADN mitocondrial. Ciencia y Mar 17: 37-42.

Gutiérrez OQ, Marinone SG, Parés-Sierra A. 2004. Lagrangian surface circulation in the Gulf of California from a 3D numerical model. Deep-Sea Res. II 51: 659-672.

Fogarty MJ, Botsford LW. 2007. Population connectivity and spatial management of marine fisheries. Oceanography 20: 112-123.

Heist J, Musick JA, Graves JE. 1996. Genetic population structure of the shortfin mako (Isurus oxyrinchus) inferred from restriction fragment length polymorphism analysis of mitochondrial DNA. Can. J. Fish. Aquat. Sci. 53(3): 583-588.

Hilário A, Metaxas A, Gaudron SM, Howell KL, Mercier A, Mestre NC, Ross RE, Thurnherr AM, Young C. 2015. Estimating dispersal distance in the deep sea: Challenges and applications to marine reserves. Front. Mar. Sci. 2: 1-14.

Hoelzel AR, Shivji MS, Magnussen J, Francis MP. 2006. Low worldwide genetic diversity in the basking shark (Cetorhinus maximus). Biol. Lett. 2: 639-642.

Huelsenbeck JP, Ronquist F. 2001. MrBayes: Bayesian estimation of phylogenetic tree. Bioinformatics 17(8): 754-755. https://doi.org/10.1093/bioinformatics/17.8.754 
Huelsenbeck JP, Ronquist F, Nielsen R, Bollback JP. 2001. Bayesian inference of phylogeny and its impact on evolutionary biology. Science 294: 2310-2314.

Hutchings JA, Reynolds JD. 2004. Marine fish population collapses: Consequences for recovery and extinction risk. Bioscience 54: 297-309.

Jacobs DK, Haney TA, Louie KD. 2004. Genes, diversity, and geologic process on the Pacific coast. Annu. Rev. Earth Planet. Sci. 32: 601-652.

Kalinowski ST. 2004. Counting alleles with rarefaction: Private alleles and hierarchical sampling designs. Conserv. Genet. 5: 539-543.

Karl SA, Castro ALF, Garla RC. 2012. Population genetics of the nurse shark (Ginglymostoma cirratum) in the western Atlantic. Mar. Biol. 159: 489-498.

Kousteni V, Kasapidis P, Kotoulas G, Megalofonou P. 2015. Strong population genetic structure and contrasting demographic histories for the small-spotted catshark (Scyliorhinus canicula) in the Mediterranean Sea. Heredity 114(3): 333-343. http://dx.doi.org/10.1038/hdy.2014.107

Kumar S, Dudley J, Nei M, Tamura K. 2008. MEGA: biologistcentric software for evolutionary analysis of DNA and protein sequences. Brief. Bioinform. 9: 299-306.

Leet WS, Dewees CM, Klingbeil R, Larson EJ. 2001. California's living marine resources: A status report. The Resources Agency, California Department of Fish and Game, Sacramento, CA, $585 \mathrm{pp}$.

Librado P, Rozas J. 2009. DnaSP v5: A software for comprehensive analysis of DNA polymorphism data. Bioinformatics 25: 1451-1452.

Manolopoulou I, Emerson BC. 2012. Phylogeographic ancestral inference using the coalescent model on haplotype trees. J. Comp. Biol. 19: 745-755.

Manolopoulou I, Legarreta L, Emerson BC, Brooks S, Tavaré S. 2011. A Bayesian approach to phylogeographic clustering. Interface Focus 1: 909-921.

Mona S, Ray N, Arenas M, Excoffier L. 2014. Genetic consequences of habitat fragmentation during a range expansion. Heredity 11: 291-299.

Moritz C. 1994. Defining 'evolutionarily significant units' for conservation. Trends Ecol. Evol. 9(10): 373-375. http://dx.doi.org/10.1016/0169-5347(94)90057-4

Nielsen JL, Powers DA. 1995. Evolution and the aquatic ecosystem: Defining unique units in population conservation. Am. Fish. Soc. Symp. 435 pp.

Nylander JAA. 2004. MrModeltest v2. Program distributed by the author. Evolutionary Biology Center, Uppsala University.

Pittenger G. 1984. Movements, distributions, feeding, and growth of the Pacific angel sharks, Squatina californica, off Santa Barbara, California. Copeia 4: 987-994.

Ramírez-Amaro SR, Cartamil D, Galván-Magaña F, GonzálezBarba G, Graham JB, Carrera-Fernández M, Escobar-Sánchez O, Sosa-Nishizaki O, Rochin-Alamillo A. 2013. The artisanal elasmobranch fishery of the Pacific coast of Baja California Sur, México, management implications. Sci. Mar. 77(3): 473-487.

Randi E. 2000. Mitochondrial DNA. In: Baker AJ (ed.), Molecular Methods in Ecology. Blackwell Science, Malden, MA, pp. 136-167.

Rogers AR, Harpending H. 1992. Population growth makes waves in the distribution of pairwise differences. Mol. Biol. Evol. 9: 552-569.

Romero-Caicedo AF, Hernández-Herrera A, Carrera-Fernández M, Galván-Magaña F. 2016. Reproductive parameters of the Pacific angel shark, Squatina californica (Selachii: Squatinidae), in the northern Mexican Pacific. J. Fish Biol. 88: 1430-1440.
Ronquist F, Huelsenbeck JP. 2003. Mr Bayes 3 v3.1.2: Bayesian phylogenetic inference under mixed models. Bioinformatics 19: 1572-1574.

Sandoval-Castillo J, Beheregaray LB. 2015. Metapopulation structure informs conservation management in a heavily exploited coastal shark (Mustelus henlei). Mar. Ecol. Prog. Ser. 533: 191-293.

Sandoval-Castillo J, Rocha-Olivares A. 2011. Deep mitochondrial divergence in Baja California populations of an aquilopelagic elasmobranch: The golden cownose ray. J. Hered. 102(3): 269-274.

Sandoval-Castillo J, Rocha-Olivares A, Villavicencio-Garayzar C, Balart E. 2004. Cryptic isolation of Gulf of California shovelnose guitarfish evidenced by mitochondrial DNA. Mar. Biol. 145: 983-988.

Schneider S, Excoffier L. 1999. Estimation of demographic parameters from the distribution of pairwise differences when the mutation rates vary among sites: Application to human mitochondrial DNA. Genetics 152: 1079-1089.

Sinclair EA, Hobbs R. 2008. Sample size effects on estimates of population genetic structure: Implications for ecological restoration. Restor. Ecol. 17: 837-844.

Smith WD, Bizzarro JJ, Richards VP, Nielsen J, Márquez-Farías F, Shivji MS. 2009. Morphometric convergence and molecular divergence: The taxonomic status and evolutionary history of Gymnura crebripunctata and Gymnura marmorata in the eastern Pacific Ocean. J. Fish Biol. 75: 761-783.

Spaet JLY, Jabado RW, Henderson AC, Moore ABM, Berumen ML. 2015. Population genetics of four heavily exploited shark species around the Arabian Peninsula. Ecol. Evol. 5: 2317-2332.

Stelbrink B, von Rintelen T, Cliff G, Kriwet J. 2009. Molecular systematics and global phylogeography of angel shark (genus Squatina). Mol. Phylogenet. Evol. 2: 395-404.

Stoner DS, Grandy JM, Priede KA, Quattro JM. 2003. Amplification primer for the mitochondrial control region and sixth intron of the nuclear-encoded lactate dehydrogenase A gene in elasmobranch fishes. Conserv. Genet. 4: 805-808.

Tajima F. 1989. Statistical methods to test for nucleotide mutation hypothesis by DNA polymorphism. Genetics 123: 585-595.

Veríssimo A, McDowell JR, Graves JE. 2011. Population structure of a deep-water squaloid shark, the Portuguese dogfish (Centroscymnus coelolepis). ICES J. Mar. Sci. 68: 555-563.

Vignaud TM, Maynard JA, Leblois R, Meekan MG, Vázquez-Juárez R, Ramírez-Macías D, Pierce S, Rowat D, Berumen ML, Beeravolu C, Baksay S, Planes S. 2014. Genetic structure of populations of whale sharks among ocean basins and evidence for their historic rise and recent decline. Mol. Ecol. 23: 2590-2601.

Villavicencio-Garayzar CJ. 1996. Aspectos poblacionales del angelito, Squatina californica, Ayres, en Baja California, México. Rev. Invest. Cient. Ser. Cienc. Mar. UABCS 1: 15-21.

Villavicencio-Garayzar CJ, Abitia-Cardenas LA. 1994. Elasmobranquios de Bahía Magdalena y Laguna San Ignacio, Baja California Sur, México. Rev. Invest. Cient. Ser. Cienc. Mar. UABCS 5: 63-67.

Weber DS, Stewart BS, Lehman N. 2004. Genetic consequences of a severe population bottleneck in the Guadalupe fur seal (Arctocephalus townsendi). J. Hered. 95: 144-153.

Received November 2016, accepted February 2017. 